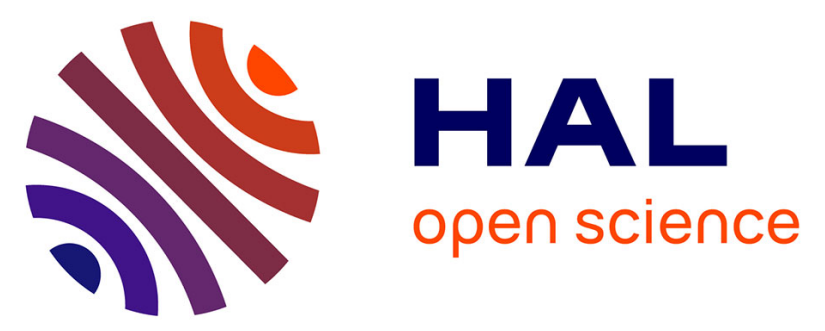

\title{
Characterization of the DNA and Membrane Interactions of a Bioreducible Cell-Penetrating Foldamer in its Monomeric and Dimeric Form
}

Christopher Aisenbrey, Céline Douat, Antoine Kichler, Gilles Guichard, Burkhard Bechinger

\section{To cite this version:}

Christopher Aisenbrey, Céline Douat, Antoine Kichler, Gilles Guichard, Burkhard Bechinger. Characterization of the DNA and Membrane Interactions of a Bioreducible Cell-Penetrating Foldamer in its Monomeric and Dimeric Form. Journal of Physical Chemistry B, 2020, 124 (22), pp.4476-4486. 10.1021/acs.jpcb.0c01853 . hal-02887798

\section{HAL Id: hal-02887798 \\ https://hal.science/hal-02887798}

Submitted on 2 Jul 2020

HAL is a multi-disciplinary open access archive for the deposit and dissemination of scientific research documents, whether they are published or not. The documents may come from teaching and research institutions in France or abroad, or from public or private research centers.
L'archive ouverte pluridisciplinaire HAL, est destinée au dépôt et à la diffusion de documents scientifiques de niveau recherche, publiés ou non, émanant des établissements d'enseignement et de recherche français ou étrangers, des laboratoires publics ou privés. 


\title{
Characterization of the DNA and Membrane Interactions of a Bioreducible Cell-penetrating Foldamer in its Monomeric and Dimeric form
}

\author{
Christopher Aisenbrey $^{1}$, Céline Douat ${ }^{2, \&}$, Antoine Kichler ${ }^{3}$, Gilles Guichard ${ }^{2}$ and \\ Burkhard Bechinger ${ }^{1,4, *}$
}

${ }^{1}$ Université de Strasbourg / CNRS, UMR7177, Institut de chimie, 4, rue Blaise Pascal, 67070 Strasbourg, France

${ }^{2}$ Université de Bordeaux/CNRS CBMN, UMR 5248, Institut Européen de Chimie et Biologie, 2 rue Robert Escarpit, 33607 Pessac, France

${ }^{3}$ Université de Strasbourg / CNRS, UMR7199, Faculté de Pharmacie, 74, route du Rhin, 67401 Illkirch, France

${ }^{4}$ Institut Universitaire de France

\& present address: Department of Pharmacy and Center for Integrated Protein Science,LudwigMaximilians-UniversitätButenandtstr. 5-13, 81377 München (Germany)

*corresponding author: Burkhard Bechinger 4, rue Blaise Pascal, 67070 Strasbourg, France

Tel.: +33 3688513 03, bechinge@ unistra.fr

Running title: mechanism of action of cell-penetrating oligoureas 


\begin{abstract}
The biophysical properties of a designed bioreducible oligourea foldamer, which shows excellent transfection activities in its dimeric form are presented. Binding isotherms of the monomer as well as of the dimer to both DNA and lipid membranes were determined by indole fluorescence. Comparing the monomer with the dimer allows both a precise biophysical characterization of the role of dimerization and how the covalent linkage between two monomers affects the transfection activity. The results indicate that dimerization results in pronounced changes in the thermodynamics of different steps of the transfection process, which extend well beyond simple steric effects within the dimer. A model emerges where the imidazole-containing polymers compact DNA at neutral $\mathrm{pH}$, but liberate the polyurea from the DNA complex at low $\mathrm{pH}$ thus being able to rupture acidified endosomes. Indeed, the dimerization inverts the $\mathrm{pH}$ dependence of the binding affinities towards the requirements suggested by this model for efficient transfection.
\end{abstract}
ABBREVIATIONS
CPP cell-penetrating peptide
DNA deoxyribonucleic acid
DPC dodecyl phosphocholine
EDTA ethylenediaminetetraacetic acid
FWHM full width at half maximum
ITC isothermal titration calorimetry
NMR nuclear magnetic resonance
PCA principal component analysis
PISEMA polarization inversion spin exchange at magic angle
POPC 1-palmitoyl-2-oleoyl-sn-glycero-3-phosphocholine
POPG 1-palmitoyl-2-oleoyl-sn-glycero-3-phospho-(1'-rac-glycerol)
SEMA spin exchange at magic angle
siRNA small interfering ribonucleic acid 


\section{INTRODUCTION}

Nucleic acids, polypeptides and drugs are molecules of high therapeutic interest, but their use in biomedical applications remains often limited by their hydrophilic character which prevents them of passing across cellular membranes ${ }^{1-2}$. Therefore, the discovery of cell-penetrating peptides (CPP) more than two decades (rather 3 since discovery of tat) ago has raised considerable interest. By helping in the transfer of proteins and drugs into the cell interior they enable valuable applications in biomedical research and bear great promise for pharmacological treatments ${ }^{3-4}$. Indeed, with several CPP-conjugated compounds being evaluated in clinical trials ${ }^{5-6}$ the use of CPPs carries big hopes also for gene therapy and gene silencing approaches where DNA and siRNA have to cross the cytoplasmic or endosomal membranes. Arginine-rich CPPs are commonly used in current applications and this class of peptides in most cases uses endosomal pathways. Unfortunately, it is often observed that the arginine-rich peptide/cargo complexes (or conjugates) are taken up rather efficiently by the cells but then endosomal escape is poor limiting their therapeutic use ${ }^{7-8}$.

Alternatively, cationic amphipathic peptides have been designed for cell-penetrating applications ${ }^{9-10}$. Among those, the histidine-containing polypeptides of the LAH4 family enable gene transfection in a highly efficient manner ${ }^{11-12}$. The LAH4 peptide sequence was originally designed using cationic antimicrobial peptides as templates ${ }^{13-14}$, numerous modifications were tested and the underlying mechanisms investigated by cell biological, biophysical and structural approaches in order to further improve the gene transfection efficiency ${ }^{12,15}$. In comparison with other non-viral transfection compounds the LAH4 peptides reach high cell penetration activities for nucleic acids and a wide variety of other cargo, including plasmid DNA and proteins of $0.5 \mathrm{MDa}$ in size ${ }^{12}$. Furthermore, LAH4 peptides have been used to improve the transfer of genetic material by lenti- or adeno associated viruses ${ }^{16-21}$.

Previous studies focused on the improvement of the amino acid sequence in the context of $\alpha$-helical peptides and to ameliorate the protocols used for cell penetration activities. Biophysical investigations revealed that the combination of four lysines, that remain positively charged throughout the transfection process, and four histidines that increase the cationic character in the endosome, is an essential feature that assures the endosomal escape of the highly efficient LAH4 peptides ${ }^{12,22-23}$.

Recently, oligourea foldamers were designed and tested that followed the same concepts which helped to develop the LAH4 transfection compounds ${ }^{24,25}$. Oligourea foldamers are characterized by a pronounced propensity to form stable helices in both organic 
${ }^{26}$ and aqueous environment ${ }^{27,28}$ whereas polypeptides are more apt to adopt a variety of secondary structures. The foldamer sequence 3 (nomenclature taken from reference ${ }^{24}$ ) $(i \mathrm{Pr}$ $\left.\mathrm{V}^{\mathrm{U}}-\mathrm{H}^{\mathrm{U}}-\mathrm{W}^{\mathrm{U}}-\mathrm{V}^{\mathrm{U}}-\mathrm{H}^{\mathrm{U}}-\mathrm{W}^{\mathrm{U}}-\mathrm{R}^{\mathrm{U}}-\gamma \mathrm{V}-\mathrm{NH}_{2}\right)$ is inspired by antimicrobial oligourea ${ }^{29,30}$ and the Hisrich composition of LAH4 peptide. Its homodimer derivative dim3 was prepared by $\mathrm{N}$ terminal thiol modification and disulfide bond formation (scheme 1 for structures). When transfection of several cell lines was tested, monomer $\mathbf{3}$ exhibited relatively low transfection activities in the absence of helper agents (such as DOPE or $\mathrm{ZnCl} 2$ ) whilst the thiol modified monomer displayed promising gene delivery capabilities even though lower than that of the LAH4 template. The homodimer $\operatorname{dim} 3$ however reached similar, if not better, activities than LAH4 without apparent toxic effects on the cells ${ }^{24}$ (see Figure S3 in the supporting information).

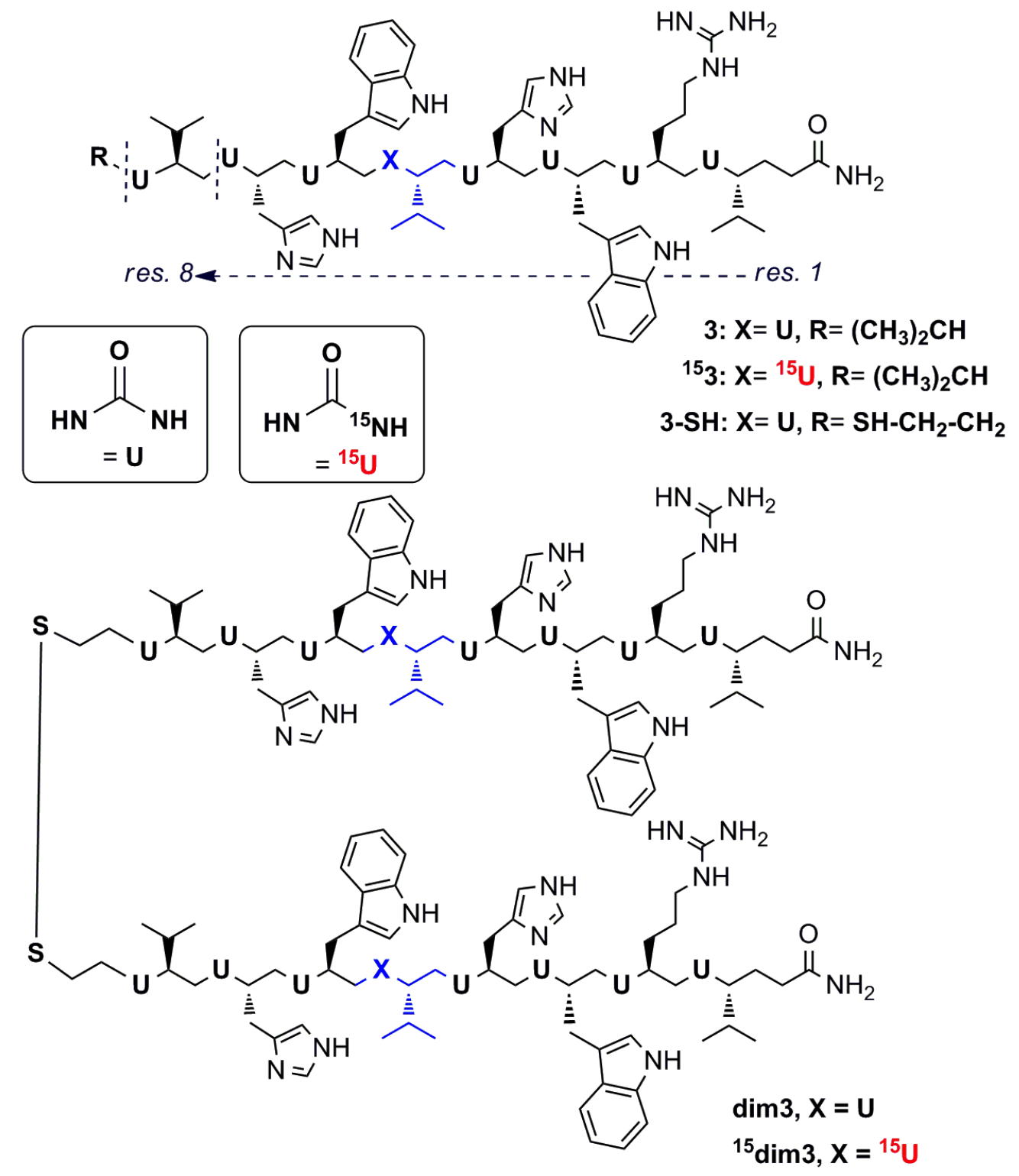

Scheme 1: Oligourea sequences of the monomer 3 and the dimer $\operatorname{dim} 3$ used during the investigations. 
The oligourea sequence $\mathbf{3}$ has been designed carrying imidazole side chains because in the LAH4 peptide the histidine residues have been shown to be essential for transfection activity ${ }^{12,23,31}$.The cationic nature of the foldamers $\mathbf{3}$ and $\operatorname{dim} \mathbf{3}$ enables the formation of compact complexes with DNA (referred as foldaplexes), a requirement for DNA uptake via the endosomes ${ }^{11,24}$. Similar to LAH4, the imidazole moieties in the cell-penetrating foldamers provide an additional feature by acquiring a positive charge when the endosomes acidify and less cationic peptide is needed to neutralize the negative charges of nucleic acids. As a consequence acidic $\mathrm{pH}$ is expected to promote the liberation of peptides/oligoureas from the nucleic acids thus they are available to disrupt the endosomal membranes ${ }^{22,31}$. Hence, according to this mechanism, an optimal transfection agent should preferably associate with DNA at high $\mathrm{pH}$ and be able to associate with the endosomal lipids at low $\mathrm{pH}$.

Because the original LAH4 peptides lack an intrinsic fluorophore, the membrane and DNA affinities are difficult to measure by fluorescence spectroscopy and require alternative approaches ${ }^{32}$. In contrast, the presence of indole rings (i.e. tryptophan-like urea-building blocks; $\operatorname{Trp}^{\mathrm{U}}$ ) in the foldamers allows one to investigate their association with both DNA and lipid membranes, and to compare those data with their transfection activity ${ }^{24}$. Furthermore, the membrane topology of the foldamers was investigated by solid-state NMR spectroscopy ${ }^{33}$. To this end, 3 and $\operatorname{dim} 3$ were prepared carrying ${ }^{15} \mathrm{~N}$ at specific sites and the foldamers reconstituted into uniaxially oriented membranes. Of these samples one and two-dimensional ${ }^{15} \mathrm{~N}$ solid-state NMR spectra were recorded. The chemical shift and dipolar couplings thus determined provide a direct indicator of the membrane topology of polypeptides ${ }^{33-34}$ and of peptide-like oligoureas ${ }^{35}$.

The foldamer was investigated in its monomeric (3) and its dimeric form (dim3) after disulfide bridge formation. This allows for the first time to compare the geometric effect of two foldamers which differ only in their size by correlating their different biological activities ${ }^{24}$ with their $\mathrm{pH}$-dependent membrane and DNA interactions. Because during the transfection process the $\mathrm{pH}$ of the environment changes from neutral during the formation of the transfection complexes to acidic in the endosomal compartment these conditions were taken into consideration.

\section{MATERIALS AND METHODS}


The preparation of oligoureas is described in reference ${ }^{24}$ where the monomer corresponds to molecule 3 and the dimer to $\operatorname{dim} 3$.

Fluorescence measurements

Vesicle preparation: a lipid solution in chloroform / methanol 2/1 v/v (POPC or POPC/POPG $2 / 1 \mathrm{~mole} / \mathrm{mole}$ ) was dried along the walls of a glass tube to form a film using a stream of nitrogen gas and by exposure to high vacuum overnight. $10 \mathrm{mM}$ phosphate buffer of the indicated $\mathrm{pH}$ containing either $1 \mathrm{mM}$ EDTA or $\mathrm{ZnCl}_{2}$ at the concentration indicated was added and the resulting lipid suspension homogenized by vortexing and four freeze thaw cycles. Small unilamellar vesicles were formed by extrusion through a polycarbonate film of $100 \mathrm{~nm}$ pore size using an Avanti mini extruder (Avanti Polar Lipids, Alabaster, AL USA). The lipid vesicles were titrated to the poly-urea solution during the experiment.

Fluorescence measurements_were performed on a Horiba FluoroLog FL3-22 photospectrometer (Horiba, Kyoto, Japan). An integration time of $0.1 \mathrm{~s}$ was used with an excitation and emission slit width of $3 \mathrm{~nm}$. The polarizer of excitation and emission were set to $0^{\circ}$ and $55^{\circ}$, respectively. The oligourea concentration was $10 \mu \mathrm{M}$ for the monomer and $5 \mu \mathrm{M}$ for the dimer in all titration experiments. The samples were buffered with $10 \mathrm{mM}$ phosphate buffer of the indicated pH. $1 \mathrm{mM}$ EDTA was present in the samples except for the samples containing $\mathrm{ZnCl}_{2}$ as indicated. EDTA was used to neutralize metal ion impurities that may be left over even in the highest grade chemicals.

The titration spectra were corrected for dilution. For each titration series a principal component analysis ${ }^{36}$ was performed in the following manner. Using Matlab (MathWorks, Natick, MA), the Eigen matrix of the covariance matrix was calculated and the component with the highest eigenvalue was normalized and interpreted as binding isotherm. In some cases, a second component was obvious, a feature that is described separately. The normalized isotherms were fitted with the equation:

$$
S\left(c_{\text {tit }}\right)=\frac{1}{\frac{k}{c_{\text {tit }}}+1} \quad \text { equ. } 1 \text {, }
$$

where $\mathrm{k}$ is the apparent association constant and $\mathrm{c}_{\mathrm{tit}}$ the concentration of lipid or DNA, respectively, added to the oligourea solution in a step-wise manner. In some cases, a linear baseline was subtracted in the fitting process.

\section{Preparation of samples for solid-state NMR spectroscopy}

Uniaxially oriented samples for solid-state NMR spectroscopy were prepared, as described in detail previously ${ }^{37}$, by co-dissolving 3.9-4.5 $\mathrm{mg}$ of ${ }^{15} \mathrm{~N}$-labelled oligourea (Scheme 1) and 
$150 \mathrm{mg}$ of 1-palmitoyl-2-oleoyl-sn-glycero-3-phosphocholine (POPC) in 1 mL trifluoroethanol. Most of the organic solvent was slowly evaporated under a stream of nitrogen and the remaining volume of about $200 \mu \mathrm{L}$ was spread onto ultra-thin cover glasses ( $8 \times 11 \mathrm{~mm}$, thickness 00, Marienfeld, Lauda-Königshofen, Germany). After drying on air, the samples were exposed to high vacuum overnight to remove all traces of organic solvents. The membranes were equilibrated at $93 \%$ relative humidity, before stacking the glass-plates on top of each other. Finally, the stacks were stabilized with Teflon tape, sealed with an escal NEO $^{\text {TM }}$ (MITSUBISHI gas chemical company, Tokyo, Japan) plastic wrapping ${ }^{38}$ and inserted into a commercial flat coil ${ }^{39}$ e-free double-resonance probe head (Bruker Biospin Rheinstetten, Germany) in such a manner that the glass plate normal is oriented parallel to the magnetic field direction of the NMR spectrometer $\left(\mathrm{B}_{0}\right)$.

\section{$\underline{\text { Solid-state NMR measurements }}$}

The one-dimensional proton-decoupled ${ }^{15} \mathrm{~N}$ solid-state NMR spectra were obtained using an Avance wide-bore spectrometer operating at 11.8 Tesla (Bruker Biospin Rheinstetten, Germany) and cross-polarization with $\mathrm{B}_{1}$ fields of $41 \mathrm{kHz}$. The ${ }^{1} \mathrm{H}^{-}{ }^{15} \mathrm{~N}$ cross polarization was applied for $800 \mu \mathrm{s}$.

Two-dimensional chemical shift/heteronuclear dipolar coupling spectra were recorded on an Avance wide-bore spectrometer operating at 9.4 Tesla (Bruker Biospin Rheinstetten, Germany) using the polarization inversion spin exchange at the magic angle (PISEMA) pulse sequence ${ }^{40}$. Briefly, after a cross polarization contact time of $800 \mathrm{~ms}$ in which polarization is transferred from ${ }^{1} \mathrm{H}$ to ${ }^{15} \mathrm{~N}$, the ${ }^{1} \mathrm{H}_{-}{ }^{15} \mathrm{~N}$ dipolar coupling is encoded during the application of a SEMA series of frequency- and phase-switched $2 \pi$ pulses. The ${ }^{1} \mathrm{H}$ - and ${ }^{15} \mathrm{~N}-\mathrm{B}_{1}$ fields during cross polarization were $83 \mathrm{kHz}$. Within the SEMA pulse train the effective ${ }^{1} \mathrm{H} /{ }^{15} \mathrm{~N}$ fields were $70 \mathrm{kHz}$ using a ${ }^{1} \mathrm{H}$ frequency offset of $\pm 40.415 \mathrm{kHz}$. The scaling factor of the PISEMA experiment (0.82) was taken into account during spectral processing 40 .

\section{$\underline{\text { Restriction analysis of solid-state NMR data }}$}

Contour plots of orientational constraints from the solid-state NMR were analysed following reference ${ }^{35}$ using the Mathematica 3.1 software (Wolfram Research, Champaign, Il, USA). The tensor for the labeled nitrogen ${ }^{35}$ was positioned inside the pdb coordinate system. To test all possible alignments in space the molecules were first rotated around the helix long axis (zaxis) and thereafter around the $y$-axis at a step size of $2^{\circ}$ around each axis ${ }^{41}$. For each alignment the chemical shift or dipolar coupling were calculated for a B-field in z-direction as 
a function of the tilt/pitch angular pairs tested in this manner. The contour plot function of Mathematica shows the orientations, where the solid-state NMR parameters agree with the measured values.

\section{pH titration by solution NMR spectroscopy}

$1.5 \mathrm{mg}$ of the monomer and $70 \mathrm{mg}$ of deuterated dodecylphosphocholine (DPC; Cambridge Isotopes, Tewksbury, MA, USA) were dissolved in $500 \mu 110 \mathrm{mM}$ deuterated citric acid (Isotec/Sigma Aldrich Miamisburg $\mathrm{OH}$, USA) in the presence of $10 \% \mathrm{D}_{2} \mathrm{O}$ and $0.02 \% \mathrm{NaN}_{3}$. The chemical shift of the imidazole 5 position was first identified from a TOCSY spectrum and followed during titration by one-dimensional ${ }^{1} \mathrm{H}$ spectroscopy using Watergate solvent suppression ${ }^{42}$. The titration curves were fitted with the function:

$$
\sigma=\frac{\sigma_{\text {prot }}+\sigma_{\text {deprot }} 10^{p H-p K_{a}}}{1+10^{p H-p K_{a}}} \quad \text { equ. } 2 \text {, }
$$

where $\sigma_{\text {prot }}$ and $\sigma_{\text {deprot }}$ are the chemical shifts of the protonated and deprotonated histidine NMR signal, respectively, $\mathrm{pK}_{\mathrm{a}}$ represents the acid dissociation of the histidine and $\mathrm{pH}$ the $\mathrm{pH}$ value of the bulk solution.

\section{RESULTS}

Monomer and dimer binding to DNA and lipid vesicles monitored by tryptophan fluorescence In a first step, nucleic acids were added to the monomer and the changes in tryptophan fluorescence characterized. Upon addition of DNA the fluorescence spectral intensities are quenched (Fig. 1A,B) probably due to stacking of the tryptophan aromatic rings and the bases of the nucleic acid ${ }^{43}$. Whereas under most conditions the peak position and line shape of the emission spectra are not significantly modified (Figure 1A) the titration of the monomer 3 with DNA at pH 5 reveals a more complex behavior (Figure 1B). At moderate ratios of DNA/3 ( 2/1 bp/oligourea) the emission spectrum is first blue-shifted from $360 \mathrm{~nm}$ to $340 \mathrm{~nm}$ before the emission maximum returns to about $355 \mathrm{~nm}$ when the concentration of DNA is further increased (Figure 1B). The series of spectra results in two non-vanishing components in a principal component analysis (PCA, Fig. S1) ${ }^{36}$ where the dominant component was fit by equation 1 (Figure 2). The analysis is indicative of an intermediate state with maximal abundance at around 20-30 $\mu \mathrm{M}$ DNA (oligourea/base pair of 1/2-1/3). The kink in the titration curve when the normalized intensities of the tryptophan fluorescence of the oligourea 
monomer are shown at $\mathrm{pH} 8$ (Figure $\mathrm{S} 2$, diamonds) suggests the presence of an intermediate state also at $\mathrm{pH} 8$, albeit not directly detectable in Figure 2A.

Titration of both the monomer 3 and the dimer $\operatorname{dim} 3$ with POPC and POPC/POPG lipid vesicles results in an increased blue shifted emission signal (from $350 \mathrm{~nm}$ to $330 \mathrm{~nm}$, Figure 1C,D) reflecting the insertion of the indole ring into the apolar environment of the lipids. The titration series with POPC and POPC/POPG vesicles were again analyzed by PCA ${ }^{36}$. Binding of 3 to POPC is higher at pH 8 when compared to $\mathrm{pH} 5$ (Fig. 2C). The differences are enhanced by $\mathrm{Zn}^{2+}$ which lowers association at low $\mathrm{pH}$ but increases binding at high $\mathrm{pH}$, where the curve is complex suggesting multiple equilibria and intermediate states (Fig. 2C). In the absence of $\mathrm{Zn}^{2+}$ binding of the monomer $\mathbf{3}$ is much increased in the presence of anionic lipid (Fig. 2C,E).

The membrane association of the $\operatorname{dim} 3$ in the absence of $\mathrm{Zn}^{2+}$ is reduced when compared to 3 and $\mathrm{pH}$ has little influence (Fig. 2D,F). However, in the presence of $\mathrm{Zn}^{2+}$ much higher affinities are observed (Fig. 2D,F). The presence of POPG increases membrane affinity also in the case of the dimer (Fig. 2D,F).

Part of the binding isotherms show features which are not well-described by equation 1 which is based on a simple membrane partitioning equilibrium (e.g. the kinks or discontinuities in Figures 2A-C, S1 and S2). Despite such insufficiencies equation 1 gives reasonable fits and good approximations of the different affinities. The resulting apparent association constants are compared in Figure 3. For the urea-based foldamer $\mathbf{3}$ the affinity to DNA is increased at low $\mathrm{pH}$ whereas for lipids the affinity increases with $\mathrm{pH}$ value (Figure $3 \mathrm{~A})$. Astonishingly this property is inverted for the dimer $(\operatorname{dim} 3)$ where the affinity for DNA is increased at high $\mathrm{pH}$ and the affinity for lipids is increased at low $\mathrm{pH}$ (Figure 3B).

The bivalent cation $\mathrm{Zn}^{2+}$ is used to enhance DNA transfection activities ${ }^{44-45}$ and has also helped to significantly increase the activities of the oligourea 3 to reach almost the level of transfection capacity of its dimer $\operatorname{dim} 3^{24}$. Interestingly when $\mathrm{ZnCl}_{2}$ is added to the DNA/foldamer formulation, the $\mathrm{pH}$ dependence of affinities of $\mathbf{3}$ to DNA are inverted when compared to the presence of EDTA (Figure 3A). When oligourea association with lipids is tested, $\mathrm{ZnCl}_{2}$ has barely an effect for the dimer and/or when the negatively charged lipid POPG is present in the membranes (Fig. 3). In contrast $\mathrm{Zn}^{2+}$ enhances the $\mathrm{pH}$ dependence of the POPC- monomer 3 interactions (Fig. 3A). Finally, when membranes made of POPC are compared to its mixture with anionic lipids (POPC/POPG) an increased affinity of the cationic oligoureas ( 3 and $\operatorname{dim} 3$ ) to the negatively charged membrane becomes evident (Fig. $3)$. 


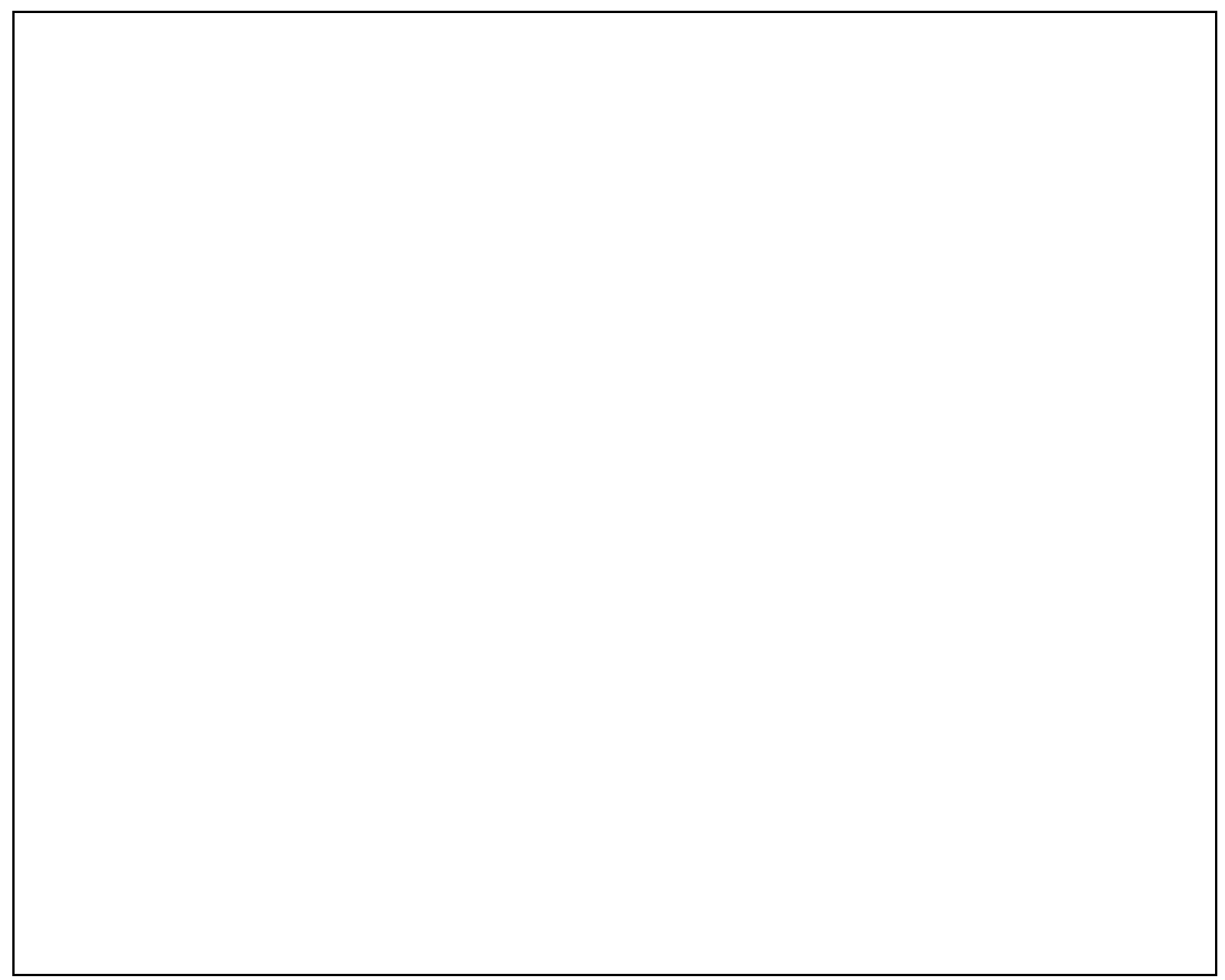

Figure 1: Titration experiments of $10 \mu \mathrm{M}$ monomer 3 with DNA (A,B) or POPC (C,D) at $\mathrm{pH}$ $8(\mathrm{~A}, \mathrm{C})$ and $\mathrm{pH} 5(\mathrm{~B}, \mathrm{D})$. The increase in intensity $<300 \mathrm{~nm}$ is due to light scattering in the presence of POPC vesicles. 


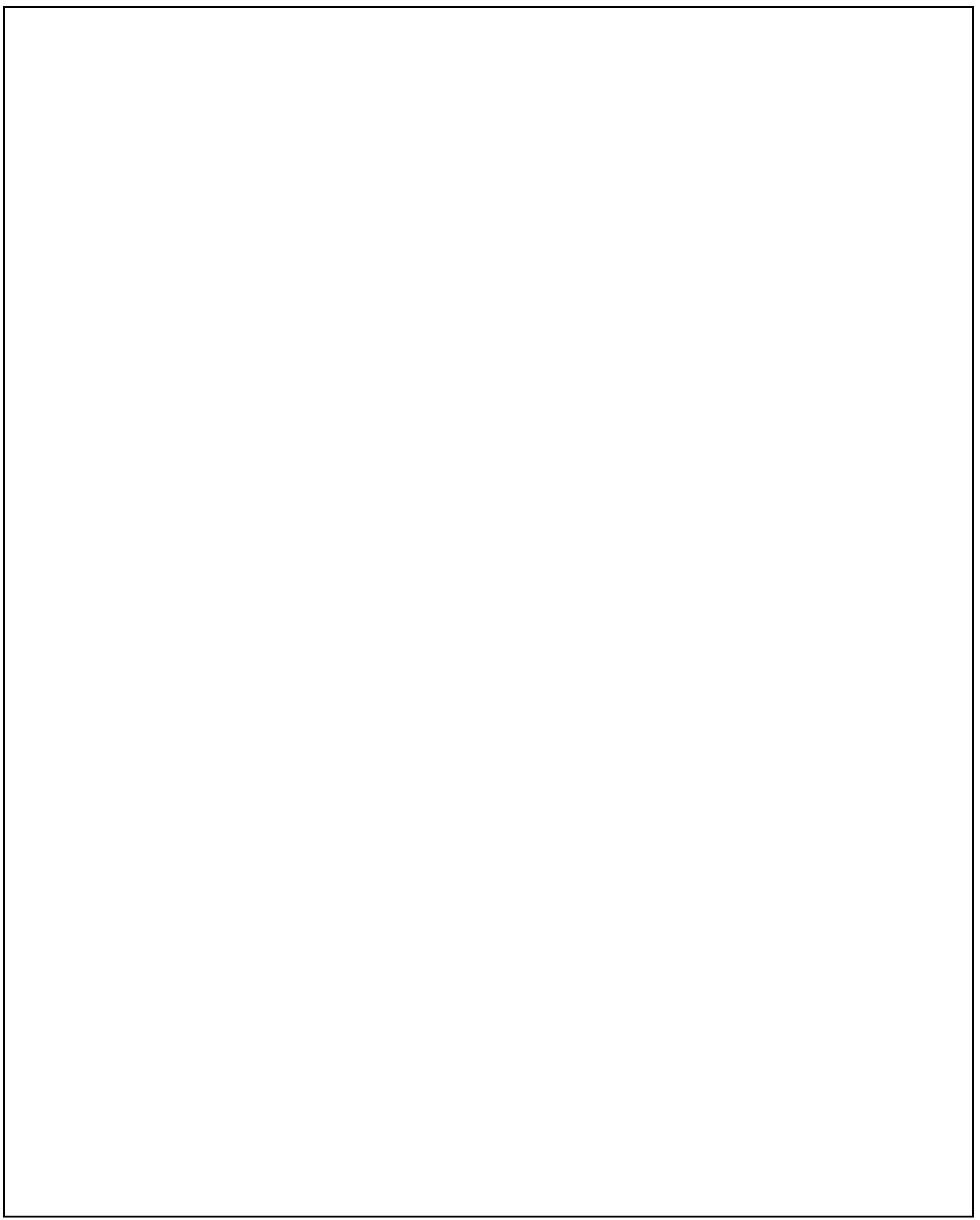

Figure 2: First component resulting from the PCA analysis of the titration experiment of 10 $\mu \mathrm{M}$ monomer $3(\mathrm{~A}, \mathrm{C}, \mathrm{E})$ and $5 \mu \mathrm{M}$ dimer $\operatorname{dim} 3(\mathrm{~B}, \mathrm{D}, \mathrm{F})$ in the presence of increasing amounts of DNA (A,B), POPC (B,C) and POPC/POPG 2/1 mole/mole (E,F). Closed symbols are recorded in the presence of EDTA and open symbols in the presence of $1 \mathrm{mM} \mathrm{ZnCl}_{2}$. Black symbols are recorded at $\mathrm{pH} 8$ and red symbols at $\mathrm{pH} 5$. 


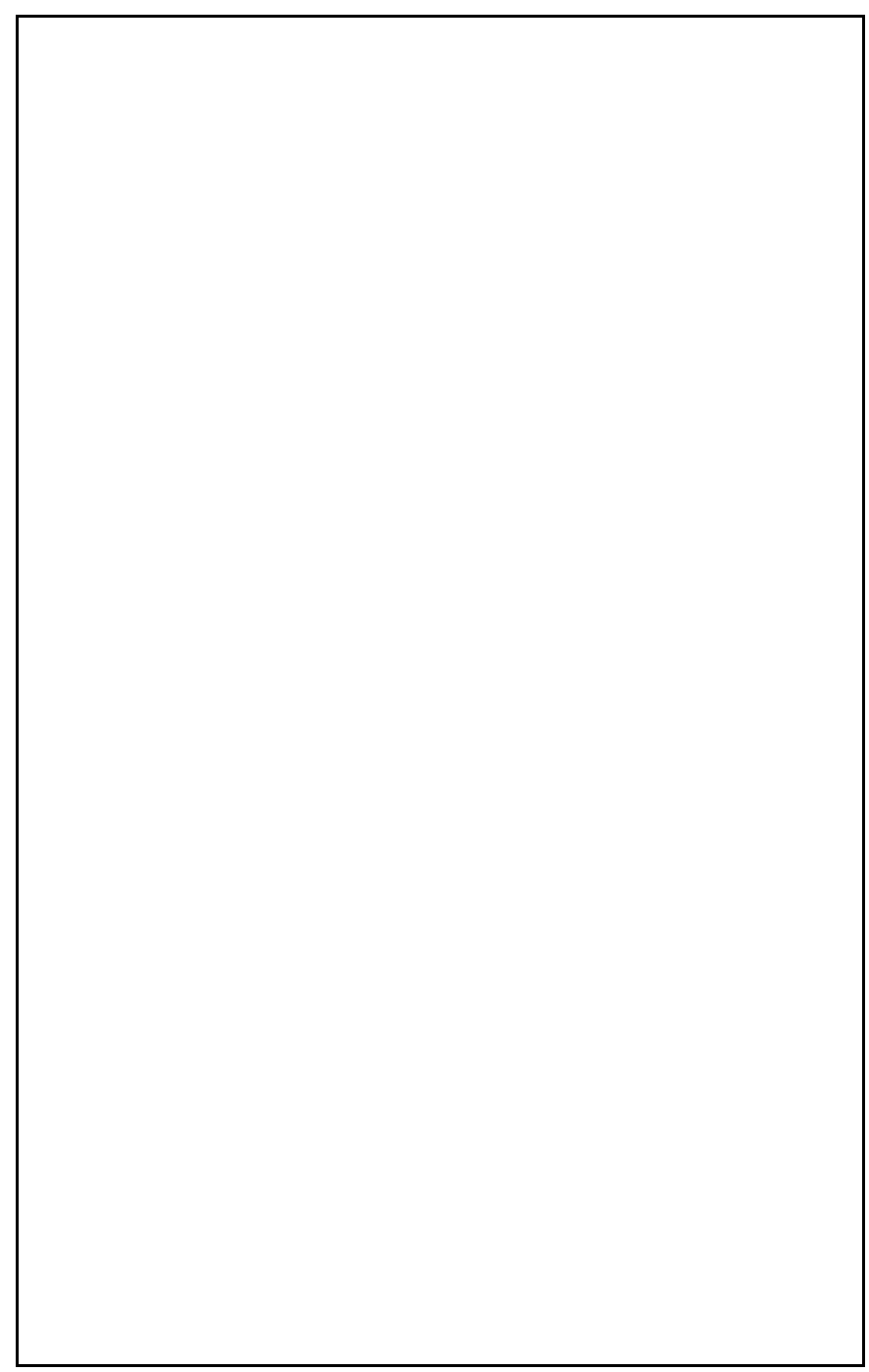

Figure 3: Binding constants of the monomer (A) and the dimer (B) to DNA (left), POPC (middle) and POPC/POPG 2/1 mole/mole (right) in presence and absence of $\mathrm{ZnCl}_{2}$. Points in black are recorded at $\mathrm{pH} 8$ and points in red are recorded at $\mathrm{pH} 5$.

\section{$\underline{\text { Solid-state NMR of oligoureas in oriented POPC lipid bilayers }}$}

In a next step monomer 3 was reconstituted into uniaxially oriented POPC bilayers and the membrane topology of the oligoureas was investigated using static solid-state NMR spectroscopy ${ }^{35}$. In a related fashion to methods that are well-established for ${ }^{15} \mathrm{~N}$-labelled peptide bonds, the ${ }^{15} \mathrm{~N}$ chemical shift and the ${ }^{1} \mathrm{H}_{-}{ }^{15} \mathrm{~N}$ dipolar couplings of oligourea ${ }^{15} \mathbf{3}$, locally ${ }^{15} \mathrm{~N}$-labelled in position of the $\mathrm{Val}^{\mathrm{U}}$ residue, directly correlate with the approximate tilt angle of helical structures ${ }^{33-35}$. For oligoureas chemical shifts $<110 \mathrm{ppm}$ are indicative of helices parallel to the surface whereas values > $130 \mathrm{ppm}$ come with transmembrane orientations $^{35}$.

When the samples have been prepared at $\mathrm{pH} 4.5$ a sharp (FWHM $\sim 250 \mathrm{~Hz})$ peak at $66.5 \mathrm{ppm}$ is observed (Figure 4A). The corresponding PISEMA spectrum, correlating the ${ }^{15} \mathrm{~N}$ 
chemical shift with the ${ }^{1} \mathrm{H}_{-}{ }^{15} \mathrm{~N}$ dipolar coupling shows a single peak with a ${ }^{1} \mathrm{H}^{-15} \mathrm{~N}$ dipolar coupling of $3.77 \mathrm{kHz}$ (Figure 4E) ${ }^{38}$. These parameters together with energetic considerations are indicative of an alignment of the oligourea $\mathbf{3}$ long axis parallel to the membrane surface (Figure 5).

Increasing the $\mathrm{pH}$ to 7 results only in small changes in the spectrum $(68.5 \mathrm{ppm} / 350$ $\mathrm{Hz}$ FWHM data not shown). However, an increase of the $\mathrm{pH}$ to 8 (Figure 4B) results in considerable spectral alterations, with a ${ }^{15} \mathrm{~N}$ chemical shift maximum at $82 \mathrm{ppm}$ and a broadening of the peak to $900 \mathrm{~Hz}$ FWHM. Hence only at pH 8 but not at neutral $\mathrm{pH}$ a significant change of the orientation of the oligourea can be detected. The addition of $\mathrm{ZnOAc}$ to ${ }^{15} \mathbf{3}$ incorporated into POPC at $\mathrm{pH} 5$ results in only a modest broadening of the peak (Figure $4 C)$.
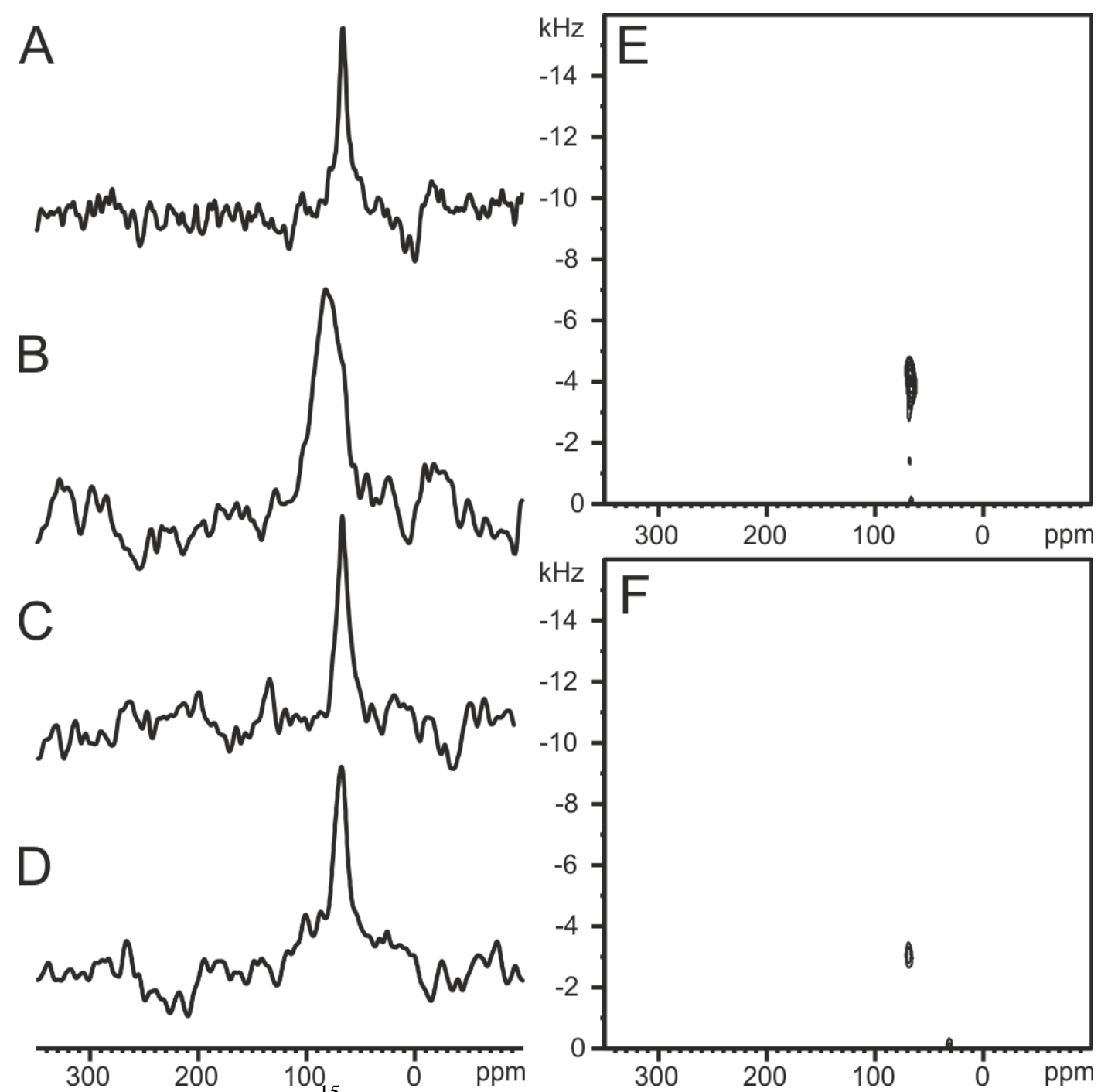

Figure 4: Proton-decoupled ${ }^{15} \mathrm{~N}$ cross polarization (A-D) and PISEMA solid-state NMR spectra (E,F) of oligoureas reconstituted into POPC bilayers oriented with the membrane normal parallel to the field of the NMR spectrometer. A and E. $4.5 \mathrm{mg} 3$ in $150 \mathrm{mg}$ POPC at pH 4.5 B. $4.5 \mathrm{mg} 3$ in $150 \mathrm{mg}$ POPC at pH 8, C. $3.9 \mathrm{mg} 3$ in $150 \mathrm{mg}$ POPC in the presence of zinc acetate at $\mathrm{pH} 5 \mathrm{D}$ and F. $2.5 \mathrm{mg} \operatorname{dim} 3$ in $150 \mathrm{mg}$ POPC at pH 4.5 . 
The spectrum of the ${ }^{15} \operatorname{dim} 3$ reconstituted into uniaxially oriented POPC shows a wellresolved peak at 68 ppm (400 Hz FWHM; Figure 4D). This is confirmed by the PISEMA spectrum with a ${ }^{15} \mathrm{~N}-{ }^{1} \mathrm{H}$ dipolar coupling of $3.07 \mathrm{kHz}$ (Figure $4 \mathrm{~F}$ ).

The thus obtained NMR data are dependent on the alignment of the molecules relative to the direction of the membrane normal (which coincides with the magnetic field direction) ${ }^{33,35}$. In order to evaluate which membrane topologies agree with the measured ${ }^{15} \mathrm{~N}$ chemical shift and ${ }^{15} \mathrm{~N}-{ }^{1} \mathrm{H}$ dipolar coupling (Fig. 4A,E) a restriction analysis was performed. For all possible orientations of the oligourea helix of $\mathbf{3}$ these two measurables were calculated and compared to the experimental data. All alignments that agree with the ${ }^{15} \mathrm{~N}$ chemical shift are labeled blue in the restriction plot shown in Figure 5A while agreement with the dipolar coupling is indicated by red traces. Only four topologies fit to both measurements and these are represented in Figure 5B. Orientation 2 represents best the amphipathic separation of the hydrophobic residues inserted into the membrane and the hydrophilic being in contact with the water phase.

Figure 5: A: restriction plot of a helical model of the monomer 3 considering $66.5 \mathrm{ppm}$ chemical shift (blue) and N-H dipolar coupling of $3.77 \mathrm{kHz}$ (red). The alignments corresponding to the different intersections are shown in $\mathrm{B}$ (red/hydrophilic $\operatorname{Arg}^{\mathrm{U}}$, $\mathrm{His}^{\mathrm{U}}$, grey/neutral $\operatorname{Trp}^{\mathrm{U}}$, blue/hydrophobic $\mathrm{Val}^{\mathrm{U}}$ ).

\section{DISCUSSION}

Previously, using cationic amphipathic antimicrobial peptides as a template, histidine-rich peptides have been designed to investigate the energetic contributions that determine if a helical peptide is aligned in transmembrane fashion or along the surface ${ }^{13,46,47}$. As expected from their design these peptides have been shown to exhibit antimicrobial ${ }^{14,48}$, but also 
potent cell-penetrating activities ${ }^{12}$ including the transfection of DNA ${ }^{11}$ and siRNA ${ }^{15}$. In order to make such transport processes into the cell interior efficient a composition of stable lysine cationic side chains and titratable histidine groups has been found important thus the overall charge changes upon endosomal acidification ${ }^{12,23}$. In order to make the same concept more amenable to in vivo applications oligourea structures more resistant to proteolytic degradation have been designed and prepared ${ }^{24}$. Whereas monomer 3 combined with $\mathrm{ZnCl} 2$ showed some promising transfection efficacy given its size, its dimerization to form $\operatorname{dim} \mathbf{3}$ via disulfide bridge formation resulted in an 8-fold improvement of activity (when comparing 3 with $\operatorname{dim} 3$ at the same mass ratio to DNA (12); see Figure S3 in the supporting information) without the need of adding $\mathrm{ZnCl}_{2}$ during foldaplex assembly. The possibility exists that disulfide bonds are reduced already at the cellular surface ${ }^{49}$, however, the much higher activity of dim3 suggests that such reactions are limited in foldaplex-type assemblies (Fig. S3). Indeed, recently it has been demonstrated that related disulfide-conjugated complexes exhibit increased stability in biological fluids ${ }^{25}$. In contrast, a high density of free -SH during the foldaplex assembly process may even result in a templating effect that trigger its oxidation into dimer ${ }^{50}$ thereby explaining the much higher activity of 3-SH when compared to $\mathbf{3}$ at high 3-SH/DNA mass ratio (Figure S3).

Here we investigated the DNA and membrane affinities of the oligourea sequences that showed the best activities in biological assays namely sequence $\mathbf{3}$ and its $\operatorname{dim} \mathbf{3}$ dimer (Scheme 1). Data were collected at neutral $\mathrm{pH}$ and under acidic conditions as they occur in the endosomes. Furthermore, the influence of $\mathrm{Zn}^{2+}$ was investigated because it has been used to enhance the transfection activities of peptides and of the oligoureas studied here ${ }^{24}$.

Previous experiments using ITC showed that the capacity of the parent LAH4 peptide to bind DNA increases when the $\mathrm{pH}$ drops below 6, i.e. when the histidines become charged ${ }^{23}$. Whereas at $\mathrm{pH} 7.4$ four lysines and the amino-terminus assure electrostatic interactions with the negatively charged nucleic acid polymer, an additional four histidines carry a positive charge at $\mathrm{pH}$ 5.5. Therefore, under acidic conditions charge neutrality of the complex is reached with about only half the amount of peptides suggesting that many of them are released when the endosome acidifies ${ }^{23}$. The underlying complexes were formed at $\mathrm{pH} 7.4$ in the presence of excess amounts of peptide. The oligoureas investigated here (Scheme 1) carry a guanidinium and two imidazole side chains (exhibiting pK-values of about 7; see SI of reference ${ }^{24}$ ) which suggests that a similar mechanism enabling endosomal escape may also apply here. 
Although the fluorescence data shown in Figures 1 and 2 do not provide information about the stoichiometry of association, the presence of indole groups in the sequence of oligoureas 3 and $\operatorname{dim} \mathbf{3}$ offers the possibility to measure binding isotherms of these molecules to DNA and lipid bilayers by fluorescence spectroscopy, results that can then be correlated to the transfection efficiency of the molecules ${ }^{24}$. The comparison of the dimer and the monomer of the same oligourea sequence allows one to reveal structural and biophysical differences which are due to the covalent conjugation of two molecules. From comparing Figure 3A and $\mathrm{B}$ it becomes obvious that the dimerization leads to more than just a slight modification of the binding behavior to DNA and lipid bilayers. Indeed, the $\mathrm{pH}$ dependence of the dimer for binding is inverted when compared to the monomer.

In the absence of $\mathrm{Zn}^{2+}$ the monomer has a higher affinity to DNA at low $\mathrm{pH}$ consistent with the binding of the cationic oligourea with the anionic DNA being driven by electrostatic interactions (Figure 3A). In the hydrophobic/interfacial environment of the DPC micelles the apparent $\mathrm{pK}$ is around $7^{24}$, a value that is expected to be even higher in the proximity of the anionic DNA polymer. Therefore, it seems reasonable to assume that not only the guanidinium but also the imidazole side chains carry cationic charges already at neutral and at acidic $\mathrm{pH}$.

The dimer on the other hand shows the opposite $\mathrm{pH}$ dependence in its DNA association (Figure 3B). Thus, it is released from the DNA upon acidification of the endosome and becomes available to interact with the membrane of this organelle. As a consequence the cargo is released into the cytoplasm, in agreement with previous models and data obtained for LAH4 peptides ${ }^{12,22}$. For this latter peptide a model was established where the DNA negative charges are saturated by the positive charges of the histidines. Less peptide is required when the LAH4 histidines take up a positive charge at the low $\mathrm{pH}$ of the endosomes thus fewer peptides are necessary to match the negative charges of the DNA. The amphipathic peptides released are then available to lyse the endosomal membranes and to assure escape of the cargo into the cytoplasm ${ }^{22-23}$.

Following a similar model, the $\mathrm{pH}$-dependent differential affinity may also explain why $\operatorname{dim} 3$ is more efficient during transfection experiments when compared to its monomer counterpart ${ }^{24}$. At the low endosomal pH the association of the amphipathic oligourea 3 does not decrease, thus molecules are not liberated from DNA to interact with the membranes which is required to ensure the best escape or DNA from this organelle ${ }^{23}$ (Figure 6A). At the present time the molecular nature of the difference in affinity remains unknown, but the interactions of monomer $\mathbf{3}$ probably involve additional energetic contributions such as 
hydrophobic and van der Waals contacts that invert the $\mathrm{pH}$ dependence when compared to the dimer.

Notably, the transfection efficiency of monomer 3 reaches almost that of the dimer in the presence of $135 \mu \mathrm{M} \mathrm{Zn}^{2+}$ ions ${ }^{24}$. At the same time the addition of $\mathrm{Zn}^{2+}$ inverts the $\mathrm{pH}$ dependence of the affinity between the oligourea and DNA, i.e. the affinity of the oligourea 3 is decreased when the $\mathrm{pH}$ is lowered, similar to the dimer in the absence of $\mathrm{Zn}^{2+}$ albeit with about 5-fold lower overall affinity (Figure 3). In contrast, the addition of $\mathrm{ZnCl}_{2}$ modifies the binding of the dimer with DNA in the opposite manner (Figure 3B) albeit without effects in the transfection assays ${ }^{24}$. This parallels observations with LAH4 peptides where it has been shown that $\mathrm{Zn}^{2+}$ only has a beneficial effect under suboptimal conditions but did not affect transfection under conditions and for polypeptide sequences where high efficiencies were already observed without the bivalent cation ${ }^{44,45}$. Thus, the $\mathrm{Zn}^{2+}$ ions must enhance a step which is not a rate limiting one in the more powerful transfection settings. The $\mathrm{Zn}^{2+}$ ions have been suggested to improve gene transfer by interactions with the phosphate group of phospholipids, thereby dehydrating the membrane and promoting membrane fusion $45,51,52$. Furthermore, $\mathrm{Zn}^{2+}$ ions have been shown to chelate imidazole groups ${ }^{53,54}$, to interact with DNA and stabilize DNA transfection complexes ${ }^{54,55}$, to promote the nuclear localization of proteins ${ }^{56}$ and to act as intracellular messenger ${ }^{57}$, all of which can have an effect on transfection processes.
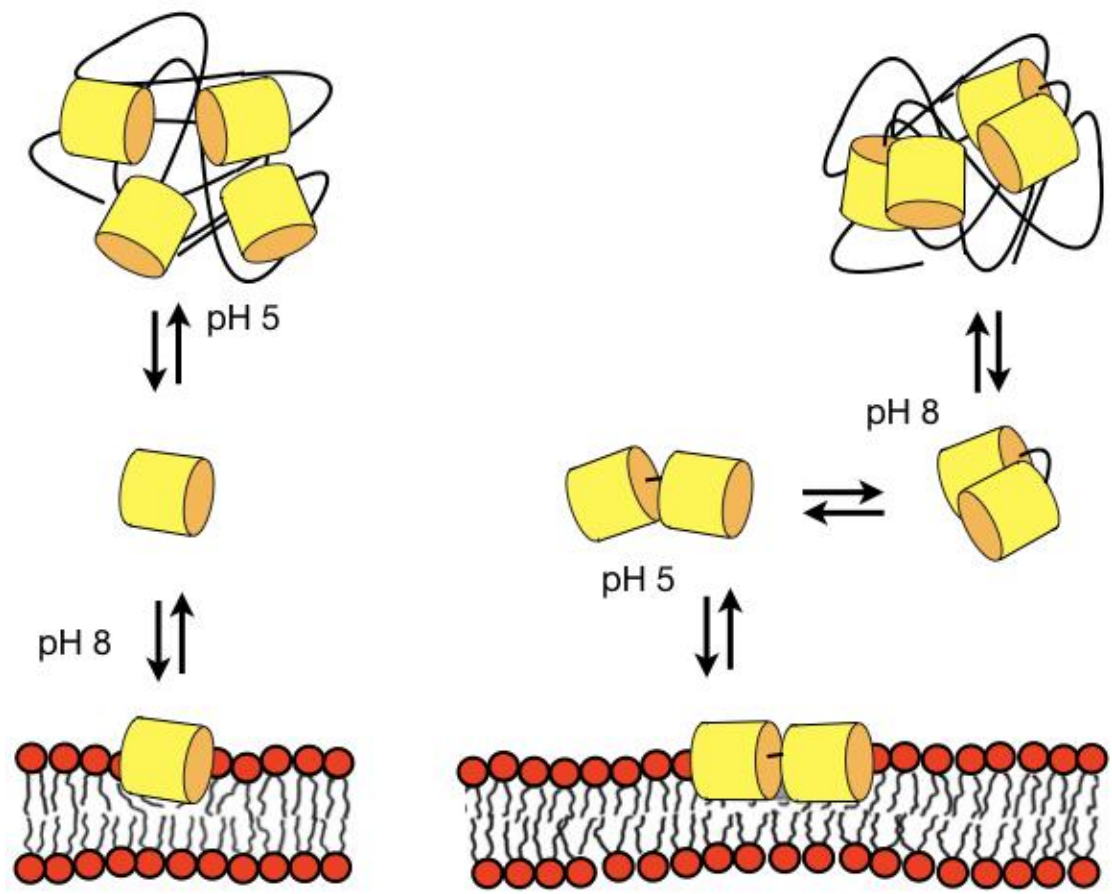

Figure 6. Model summarizing the $\mathrm{pH}$-dependence of the membrane and DNA association of A. monomer 3 and B. the disulfide-conjugated $\operatorname{dim} 3$. The helical monomer unit is sketched by a yellow cylinder, the DNA by the black coil in the top part of the Figure. 
When lipid association is studied, interesting differences are observed between the monomer and the dimer. The monomer $\mathbf{3}$ exhibits a significantly higher association to neutral POPC at pH 8 when compared to $\mathrm{pH} 5$ (Figures 3A and 6A) suggesting that hydrophobic interactions are important but the apparent binding is modulated by repulsive interactions once a first layer of the cationic peptides is associated with the membrane surface. Notably the alignment of the peptide is not altered by the $\mathrm{pH}$ (Figure 4). Such behavior has been analyzed by the Gouy-Chapman formalism where the surface charge density depends on the amount of surface-associated cationic oligourea (or peptide) ${ }^{58}$. Indeed, for the binding to anionic membranes (POPC/POPG) this $\mathrm{pH}$ dependence is almost completely abolished (Figure $3 \mathrm{~A}$ ) because peptides or the oligoureas studied here are initially attracted by charge complementarity up to the point when charge neutrality at the surface is achieved.

Again, $\operatorname{dim} 3$ shows the opposite behavior, by binding better to zwitterionic membranes at low $\mathrm{pH}, \mathrm{a} \mathrm{pH}$ dependence that is conserved also for the anionic membranes (POPC/POPG 2/1 mole/mole) (Figures 3B and 6B). When compared with the monomer, the adsorption of the dimer to the membranes is reduced at $\mathrm{pH} 8$ but increased at $\mathrm{pH} 5$ (Figure 3). This indicates that at high $\mathrm{pH}$ the membrane adsorption is limited by an additional process which is independent from the previously described electrostatic interactions. It seems plausible that the hydrophobic faces of the two oligourea segments are folded onto each other and become only available for membrane association through conformational rearrangements.

In contrast, at low $\mathrm{pH} \operatorname{dim} 3$ is driven to the membrane probably because it already adopts a more extended (rather than a hairpin) conformation and membrane-association occurs by cooperative insertion of the two subunits (Figure 6B). Once $\operatorname{dim} 3$ is bound to the endosomal membrane at low $\mathrm{pH}$ an extended topology similar to that of the monomer is privileged (Figures 4A,E and 6). Thereby, in the context of the common model for peptideassisted transfection ${ }^{23,31}$ the behavior of $\operatorname{dim} 3$ fits better since it is less membrane active at high $\mathrm{pH}$ and hence doesn't perturb the membrane before the endosome gets acidified.

Notably, dimerization of $\mathbf{3}$ via disulfide bridge formation changes the properties of the oligourea in a comprehensive manner, which goes well beyond purely geometric considerations. The titration series contains some indication of the more complex nature of the binding events (Figs. 2, S1, S2). Clearly the fluorescence spectra of the monomer 3 in the presence of increasing amounts of DNA at pH 5 (Figure 1B) cannot be described by simply adding contributions of a free and a bound fraction. Indeed, an intermediate population is 
revealed by principal component analysis (Figure S1). Probably this "intermediate" state (open symbols) reflects a more condensed structure of the DNA-oligourea complex at high polyurea/DNA ratio, whereas in the presence of an excess amount of DNA a transition to a more open structure occurs. Indeed, the blue shift in the fluorescence spectra indicates a more tightly packed conformation at high oligourea concentration where the indole rings are less exposed to the polar water environment (Figure 1B).

According to the oriented solid-state NMR data at low $\mathrm{pH}$ both the monomer and the dimer are aligned parallel to the bilayer surface with no significant difference (Figures 4A,D and 5). At higher $\mathrm{pH}$ (Figure 4B) the resonances are slightly shifted to increased ${ }^{15} \mathrm{~N}$ chemical shift values, however, the oligourea helix does not adopt a transmembrane configuration. Also, the addition of zinc acetate seems to result in only a slight broadening of the peak towards higher chemical shift values (Figure 4C). Hence, knowing that the structures of these foldamers are rather stable in a multitude of environments ${ }^{59}$ and in view of the little topological changes reflected in the oriented ${ }^{15} \mathrm{~N}$ solid-state NMR spectra, the difference in transfection efficiency is likely not linked to structural changes of the membrane-associated oligourea. The data presented in this paper rather suggest that the pronounced differences in how the mono- and dimeric oligourea reversibly associates with DNA contributes to the differences in transfection. They are suggestive that electrostatic complexation of the nucleic acids together with an equilibrium between stable and $\mathrm{pH}$-dependent charges of the oligourea in the physiological range of the endosome, make important contributions, that are further modulated by the presence of bivalent $\mathrm{Zn}^{2+}$ ions.

\section{CONCLUSIONS}

The data presented in this paper clearly show that increased affinity for DNA at high $\mathrm{pH}$ and increased affinity for lipids at low $\mathrm{pH}$ correlate well with the transfection efficiency ${ }^{23}$. On the one hand, this validates a physico-chemical approach for the rational development of optimized vectors for gene transfection. On the other hand, the data is in line with the previously established model where the disruption of acidified endosomes has been suggested to explain the very efficient transfection of nucleic acids and endosomal escape of other cargo when LAH4 peptides are used ${ }^{12,16,22,23}$.

However, the data shows that the adsorption process of the foldamers to both DNA and lipids is complex and difficult to predict. The binding isotherms suggest the presence of intermediate states and saturation is difficult to achieve in both cases. Therefore, at the present 
state it is necessary to experimentally measure the binding affinities of new transfection agent candidates in order to verify that the rational design generates the desired results.

SUPPORTING INFORMATION: monomer 3 association with DNA at pH 5, normalized emission signal of $\mathbf{3}$ upon DNA titration, transfection of HEK293 cells with $p$-luc with different vectors.

\section{ACKNOWLEDGEMENTS}

The financial contributions of the Agence Nationale de la Recherche (projects TRANSPEP 07-PCV-0018, Biosupramol 17-CE18-0033-3 and the LabEx Chemistry of Complex Systems 10-LABX-0026_CSC), the University of Strasbourg (including an Idex attractivity grant to CA), the CNRS, the Région Alsace and the RTRA International Center of Frontier Research in Chemistry are gratefully acknowledged. BB is grateful to the Institut Universitaire de France for providing additional time to be dedicated to research.

\section{REFERENCES (check once all changes have been made)}

1. Broeders, M.; Herrero-Hernandez, P.; Ernst, M. P. T.; van der Ploeg, A. T.; Pijnappel, W., Sharpening the Molecular Scissors: Advances in Gene-Editing Technology. iScience 2019, 23 (1), 100789.

2. Lee, M. R.; Jayant, R. D., Penetration of the blood-brain barrier by peripheral neuropeptides: new approaches to enhancing transport and endogenous expression. Cell Tissue Res 2019, 375 (1), 287-293.

3. Ramsey, J. D.; Flynn, N. H., Cell-penetrating peptides transport therapeutics into cells. Pharmacol Ther 2015, 154, 78-86.

4. $\quad \mathrm{Xu}$, J.; Khan, A. R.; Fu, M.; Wang, R.; Ji, J.; Zhai, G., Cell-penetrating peptide: a means of breaking through the physiological barriers of different tissues and organs. J Control Release 2019, 309, 106-124.

5. Torchilin, V. P., Multifunctional, stimuli-sensitive nanoparticulate systems for drug delivery. Nature Reviews Drug Discovery 2014, 13 (11), 813-827.

6. $\quad$ Kurrikoff, K.; Langel, U., Recent CPP-based applications in medicine. Expert Opin Drug Deliv 2019, 16 (11), 1183-1191.

7. Pei, D.; Buyanova, M., Overcoming Endosomal Entrapment in Drug Delivery. Bioconjug Chem 2019, 30 (2), 273-283.

8. Johannes, L.; Lucchino, M., Current Challenges in Delivery and Cytosolic Translocation of Therapeutic RNAs. Nucleic Acid Ther 2018, 28 (3), 178-193.

9. Crombez, L.; drian-Herrada, G.; Konate, K.; Nguyen, Q. N.; McMaster, G. K.; Brasseur, R.; Heitz, F.; Divita, G., A new potent secondary amphipathic cell-penetrating peptide for siRNA delivery into mammalian cells. Mol Ther. 2009, 17 (1), 95-103. 
10. Midoux, P.; Pichon, C.; Yaouanc, J. J.; Jaffres, P. A., Chemical vectors for gene delivery: a current review on polymers, peptides and lipids containing histidine or imidazole as nucleic acids carriers. British Journal of Pharmacology 2009, 157 (2), 166-178.

11. Kichler, A.; Leborgne, C.; März, J.; Danos, O.; Bechinger, B., Histidine-rich amphipathic peptide antibiotics promote efficient delivery of DNA into mammalian cells. Proc.Natl.Acad.Sci.U.S.A. 2003, 100 (4), 1564-1568.

12. Moulay, G.; Leborgne, C.; Mason, A. J.; Aisenbrey, C.; Kichler, A.; Bechinger, B., Histidine-rich designer peptides of the LAH4 family promote cell delivery of a multitude of cargo. J Pept Sci 2017, 23 (4), 320-328.

13. Bechinger, B., Towards membrane protein design: $\mathrm{pH}$-sensitive topology of histidinecontaining polypeptides. J.Mol.Biol. 1996, 263 (5), 768-775.

14. Vogt, T. C. B.; Bechinger, B., The interactions of histidine-containing amphipathic helical peptide antibiotics with lipid bilayers: The effects of charges and $\mathrm{pH}$. Journal of Biological Chemistry 1999, 274, 29115-29121.

15. Langlet-Bertin, B.; Leborgne, C.; Scherman, D.; Bechinger, B.; Mason, A. J.; Kichler, A., Design and evaluation of histidine-rich amphipathic peptides for siRNA delivery. Pharm Res 2010, 27 (7), 1426-36.

16. Liu, N.; Bechinger, B.; Suss, R., The histidine-rich peptide LAH4-L1 strongly promotes PAMAM-mediated transfection at low nitrogen to phosphorus ratios in the presence of serum. Sci Rep 2017, 7 (1), 9585.

17. Majdoul, S.; Seye, A. K.; Kichler, A.; Holic, N.; Galy, A.; Bechinger, B.; Fenard, D., Molecular Determinants of Vectofusin-1 and Its Derivatives for the Enhancement of Lentivirally Mediated Gene Transfer into Hematopoietic Stem/Progenitor Cells. J Biol Chem 2016, 291 (5), 2161-9.

18. Gemmill, K. B.; Muttenthaler, M.; Delehanty, J. B.; Stewart, M. H.; Susumu, K.; Dawson, P. E.; Medintz, I. L., Evaluation of diverse peptidyl motifs for cellular delivery of semiconductor quantum dots. Analytical and Bioanalytical Chemistry 2013, 405 (19), 61456154.

19. Zhang, T. T.; Khang, T. H.; Ma, B.; Xu, Y.; Hung, C. F.; Wu, T. C., LAH4 enhances CD8+ T cell immunity of protein/peptide-based vaccines. Vaccine 2011, 30 (4), 784-793.

20. Fenard, D.; Ingrao, D.; Seye, A.; Buisset, J.; Genries, S.; Martin, S.; Kichler, A.; Galy, A., Vectofusin-1, a new viral entry enhancer, strongly promotes lentiviral transduction of human hematopoietic stem cells. Mol Ther Nucleic Acids 2013, 2, e90.

21. Liu, Y.; Kim, Y. J.; Ji, M.; Fang, J.; Siriwon, N.; Zhang, L.; Wang, P., Enhancing gene delivery of adeno-associated viruses by cell-permeable peptides. Molecular Therapy Methods \& Clinical Development 2014, 1 (12), doi:10.1038/mtm.2013.12.

22. Wolf, J.; Aisenbrey, C.; Harmouche, N.; Raya, J.; Bertani, P.; Voievoda, N.; Süss, R.; Bechinger, B., pH-dependent membrane interactions of the histidine-rich cell penetrating peptide LAH4-L1 Biophysical Journal 2017, 113 (6), 1290-1300.

23. Prongidi-Fix, L.; Bertani, P.; Bechinger, B., The membrane alignment of helical peptides from non-oriented $15 \mathrm{~N}$ chemical shift solid-state NMR spectroscopy.

J.Am.Chem.Soc. 2007, 129, 8430-8431.

24. Douat, C.; Aisenbrey, C.; Antunes, S.; Decossas, M.; Lambert, O.; Bechinger, B.; Kichler, A.; Guichard, G., A Cell-Penetrating Foldamer with a Bioreducible Linkage for Intracellular Delivery of DNA. Angew Chem Int Ed Engl 2015, 54 (38), 11133-7.

25. Douat, C.; Bornerie, M.; Antunes, S.; Guichard, G.; Kichler, A., Hybrid CellPenetrating Foldamer with Superior Intracellular Delivery Properties and Serum Stability. Bioconjug Chem 2019, 30 (4), 1133-1139.

26. Pendem, N.; Douat, C.; Claudon, P.; Laguerre, M.; Castano, S.; Desbat, B.; Cavagnat, D.; Ennifar, E.; Kauffmann, B.; Guichard, G., Helix-forming propensity of aliphatic urea 
oligomers incorporating noncanonical residue substitution patterns. J Am Chem Soc 2013, 135 (12), 4884-92.

27. Collie, G. W.; Pulka-Ziach, K.; Lombardo, C. M.; Fremaux, J.; Rosu, F.; Decossas, M.; Mauran, L.; Lambert, O.; Gabelica, V.; Mackereth, C. D.; Guichard, G., Shaping quaternary assemblies of water-soluble non-peptide helical foldamers by sequence manipulation. Nat Chem 2015, 7 (11), 871-8.

28. Collie, G. W.; Bailly, R.; Pulka-Ziach, K.; Lombardo, C. M.; Mauran, L.; TaibMaamar, N.; Dessolin, J.; Mackereth, C. D.; Guichard, G., Molecular Recognition within the Cavity of a Foldamer Helix Bundle: Encapsulation of Primary Alcohols in Aqueous Conditions. J Am Chem Soc 2017, 139 (17), 6128-6137.

29. Claudon, P.; Violette, A.; Lamour, K.; Decossas, M.; Fournel, S.; Heurtault, B.; Godet, J.; Mely, Y.; Jamart-Gregoire, B.; Averlant-Petit, M. C.; Briand, J. P.; Duportail, G.; Monteil, H.; Guichard, G., Consequences of isostructural main-chain modifications for the design of antimicrobial foldamers: helical mimics of host-defense peptides based on a heterogeneous amide/urea backbone. Angew Chem Int Ed Engl 2010, 49 (2), 333-6.

30. Antunes, S.; Corre, J. P.; Mikaty, G.; Douat, C.; Goossens, P. L.; Guichard, G., Effect of replacing main-chain ureas with thiourea and guanidinium surrogates on the bactericidal activity of membrane active oligourea foldamers. Bioorg Med Chem 2017, 25 (16), 42454252.

31. Kichler, A.; Mason, A. J.; Bechinger, B., Cationic amphipathic histidine-rich peptides for gene delivery. Biochimica et Biophysica Acta 2006, 1576, 301-307.

32. Voievoda, N.; Schulthess, T.; Bechinger, B.; Seelig, J., Thermodynamic and Biophysical Analysis of the Membrane-Association of a Histidine-Rich Peptide with Efficient Antimicrobial and Transfection Activities. J Phys Chem B 2015, 119 (30), 9678-87.

33. Bechinger, B.; Resende, J. M.; Aisenbrey, C., The structural and topological analysis of membrane-associated polypeptides by oriented solid-state NMR spectroscopy: Established concepts and novel developments. Biophys Chem 2011, 153, 115-125.

34. Bechinger, B.; Sizun, C., Alignment and structural analysis of membrane polypeptides by $15 \mathrm{~N}$ and $31 \mathrm{P}$ solid-state NMR spectroscopy Concepts in Magnetic Resonance 2003, 18A, $130-145$

35. Aisenbrey, C.; Pendem, N.; Guichard, G.; Bechinger, B., Solid state NMR studies of oligourea foldamers: Interaction of N-15-labelled amphiphilic helices with oriented lipid membranes. Organic \& Biomolecular Chemistry 2012, 10 (7), 1440-1447.

36. Pearson, K., On Lines and Planes of Closest Fit to Systems of Points in Space. Philosophical Magazine Series 6 1901, (2), 559-572.

37. Bechinger, B.; Bertani, P.; Werten, S.; Mendonca de Moraes, C.; Aisenbrey, C.; Mason, A. J.; Perrone, B.; Prudhon, M.; Sudheendra, U. S.; Vidovic, V., The structural and topological analysis of membrane polypeptides by oriented solid-state NMR spectroscopy: Sample preparation and theory. In Membrane-active peptides: Methods and results on structure and function, Castanho, M., Ed. International University Line: La Jolla, California, USA, 2010; pp 196-215

38. Aisenbrey, C.; Bertani, P.; Bechinger, B., Solid-state NMR investigations of membrane-associated antimicrobial peptides. In Antimicrobial Peptides Guiliani, A.; Rinaldi, A. C., Eds. Humana Press, Springer: N.Y., 2010; pp 209-233.

39. Bechinger, B.; Opella, S. J., Flat-Coil Probe for NMR Spectroscopy of Oriented Membrane Samples. J.Magn.Reson. 1991, 95, 585-588.

40. Ramamoorthy, A.; Wei, Y.; Lee, D., PISEMA Solid-State NMR Spectroscopy. Annual Reports on NMR Spectroscopy 2004, 52, 1-52.

41. Aisenbrey, C.; Sizun, C.; Koch, J.; Herget, M.; Abele, U.; Bechinger, B.; Tampe, R., Structure and dynamics of membrane-associated ICP47, a viral inhibitor of the MHC I antigen-processing machinery. J. Biol. Chem. 2006, 281, 30365-30372. 
42. Piotto, M.; Saudek, V.; Sklenar, V., Gradient-tailored excitation for single-quantum NMR spectroscopy of aqueous solutions. J.Biomol.NMR 1992, 2 (6), 661-665.

43. Brun, F.; Toulme, J. J.; Helene, C., Interactions of aromatic residues of proteins with nucleic acids. Fluorescence studies of the binding of oligopeptides containing tryptophan and tyrosine residues to polynucleotides. Biochemistry 1975, 14 (3), 558-63.

44. Kichler, A.; Leborgne, C.; Danos, O.; Bechinger, B., Characterization of the gene transfer process mediated by histidine-rich peptides. J Mol Med. 2007, 85 (2), 191-201. 45. Pichon, C.; Guerin, B.; Refregiers, M.; Gonáalves, C.; Vigny, P.; Midoux, P., Zinc Improves Gene Transfer-Mediated by DNA/Cationic Polymer Complexes. Journal of Gene Medicine 2002, (4), 548-59.

46. Aisenbrey, C.; Kinder, R.; Goormaghtigh, E.; Ruysschaert, J. M.; Bechinger, B., Interactions involved in the realignment of membrane-associated helices: An investigation using oriented solid-state NMR and ATR-FTIR spectroscopies topologies J. Biol. Chem. 2006, 281, 7708-7716.

47. Aisenbrey, C.; Goormaghtigh, E.; Ruysschaert, J. M.; Bechinger, B., Translocation of amino acyl residues from the membrane interface to the hydrophobic core: Thermodynamic model and experimental analysis using ATR-FTIR spectroscopy. Molecular Membrane Biology 2006, 23, 363-374.

48. Mason, A. J.; Gasnier, C.; Kichler, A.; Prevost, G.; Aunis, D.; Metz-Boutigue, M. H.; Bechinger, B., Enhanced membrane disruption and antibiotic action against pathogenic bacteria by designed histidine-rich peptides at acidic $\mathrm{pH}$. Antimicrob.Agents Chemother. 2006, 50 (10), 3305-3311.

49. Aubry, S.; Burlina, F.; Dupont, E.; Delaroche, D.; Joliot, A.; Lavielle, S.; Chassaing, G.; Sagan, S., Cell-surface thiols affect cell entry of disulfide-conjugated peptides. FASEB J 2009, 23 (9), 2956-67.

50. Hashim, P. K.; Okuro, K.; Sasaki, S.; Hoashi, Y.; Aida, T., Reductively Cleavable Nanocaplets for siRNA Delivery by Template-Assisted Oxidative Polymerization. J Am Chem Soc 2015, 137 (50), 15608-11.

51. Binder, H.; Arnold, K.; Ulrich, A. S.; Zschornig, O., The effect of Zn2+ on the secondary structure of a histidine-rich fusogenic peptide and its interaction with lipid membranes. Biochimica et Biophysica Acta - Biomembranes 2000, 1468 (1-2), 345-358. 52. Fang, H.; Lin, L.; Chen, J.; Wu, J.; Tian, H.; Chen, X., Zinc ion coordination significantly improved the transfection efficiency of low molecular weight polyethylenimine. Biomater Sci 2019, 7 (4), 1716-1728.

53. Pavletich, N. P.; Pabo, C. O., Zinc finger-DNA recognition: crystal structure of a Zif268-DNA complex at 2.1 A. Science 1991, 252 (5007), 809-17.

54. Asayama, S.; Nishinohara, S.; Kawakami, H., Zinc-chelated imidazole groups for DNA polyion complex formation. Metallomics 2011, 3 (7), 680-2.

55. Asayama, S.; Sakata, M.; Kawakami, H., Structure-activity relationship between $\mathrm{Zn}(2+)$-chelated alkylated poly(1-vinylimidazole) and gene transfection. J Inorg Biochem 2017, 173, 120-125.

56. Kabu, K.; Yamasaki, S.; Kamimura, D.; Ito, Y.; Hasegawa, A.; Sato, E.; Kitamura, H.; Nishida, K.; Hirano, T., Zinc is required for Fc epsilon RI-mediated mast cell activation. $J$ Immunol 2006, 177 (2), 1296-305.

57. Yamasaki, S.; Sakata-Sogawa, K.; Hasegawa, A.; Suzuki, T.; Kabu, K.; Sato, E.; Kurosaki, T.; Yamashita, S.; Tokunaga, M.; Nishida, K.; Hirano, T., Zinc is a novel intracellular second messenger. J Cell Biol 2007, 177 (4), 637-45.

58. Wieprecht, T.; Apostolov, O.; Beyermann, M.; Seelig, J., Membrane binding and pore formation of the antibacterial peptide PGLa: thermodynamic and mechanistic aspects.

Biochemistry 2000, 39 (2), 442-452. 
59. Fischer, L.; Guichard, G., Folding and self-assembly of aromatic and aliphatic urea oligomers: towards connecting structure and function. Org Biomol Chem 2010, 8 (14), 310117.

TOC
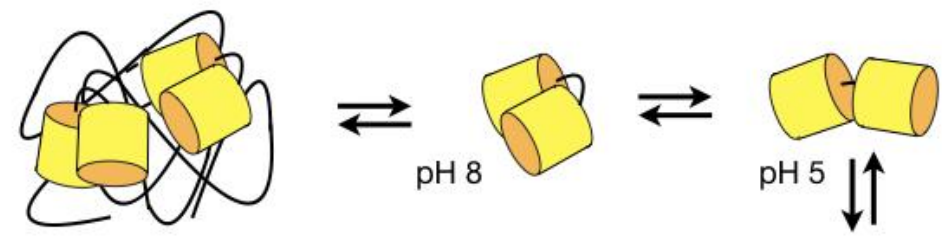

oligourea-DNA foldaplex

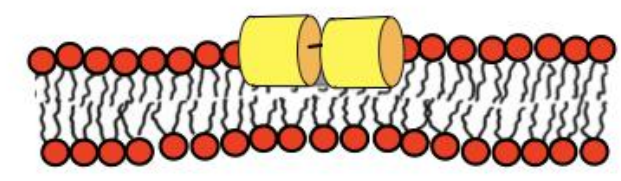

